\title{
Relationship between Human Resources Management Variables and the Academic Performance of Students in Secondary Schools in Egor Local Government Area, Edo State, Nigeria
}

\author{
Dr. Roseline 0. Osagie \\ University of Benin, Faculty of Education, University of Benin, Edo State - Edo State, Nigeria \\ rosarugue@yahoo.co.uk \\ Dr. Chukujindu J. Okafor \\ Benson Idahosa University, Faculty of Education, Edo State - Edo State, Nigeria \\ chukujinduokafor@yahoo.com
}

\section{Doi:10.5901/jesr.2015.v5n1p323}

\begin{abstract}
This is a quantitative study which investigated how human resources management variables impacted the academic performance of students in secondary schools in Egor local government area of Edo State in 2006 and 2007. Four hypotheses were formulated. A questionnaire of the human resources management variables was administered to test the hypotheses. Pearson product-moment correlation coefficient was used to analyse the relationship between the four dimensions of human resources management variables and the academic performance of students. Findings demonstrated support for the hypotheses relative to three dimensions of the variables and students' performance. The study determined that staff workload had a negative correlation with students' performance while human resources planning, staff supervision and staff evaluation had a positive correlation to students' academic performance.
\end{abstract}

Keywords: Human resources variables. management, students' performance, secondary schools, Edo State, Nigeria

\section{Introduction}

Over the years, educational institutions have developed into complex and functional field of endeavour from the previous simple experiences. Changes in technology, economic, social and political sectors have contributed immensely to this development. Therefore, for educational institutions to stay abreast in this rapidly changing environment, they must adapt to the new technologies and the changing life world. These issues pose many problems and challenges for school managers. Consequently, the management of physical and human resources in the school system are of the utmost importance in order to achieve the overall goals and objectives of the schools.

Technological advancement has resulted in the use of new methods of teaching while government intervention in education has induced constant changes in national educational policies in Nigeria. Also, the demand for better pay, more benefits, less work by the staff and the lack of basic infrastructure in the schools are some of the problems the human resources manager has to cope with and manage properly to enable him meet the set goals and objectives of the school system ( Peretomode and Peretomode, 2005). Human resources management in education implies effectively coordinating the activities of staff, students and parents so as to achieve educational aims and objectives (Adeniyi, 2004). The National Policy on Education (2004) clearly spells out the broad responsibilities of managing schools as employment, promotion, deployment and discipline of teachers among others.

Successive governments in Nigeria have made efforts towards the effective management of human resources in educational institutions. However, certain challenges still persist with staff training and development, teachers' workload, performance evaluation, supervision of instruction, conditions of service, staff turnover and motivation, disciplinary problems among students and teachers, promotion policies and so on.

To adequately handle the forgoing challenges, efforts should be geared towards the effective management of staff and students in secondary schools. The importance of human resources management has been stated but there is not much information on its relationship with the academic performance of students in secondary schools. High academic 
performance is one of the objectives of secondary education in Nigeria. For secondary schools to achieve high performance in the public examinations, they must recruit qualified teachers, they should secure modern buildings, adequate facilities and equipment should be provided to enhance teaching and learning while supervision of teaching is carried out for quality control. Other bodies that could influence students' academic performance are administrators, managers, guidance counsellors, Parents Teachers Association (PTA), curriculum specialist, funding agencies, non teaching staff, inspectors and examination boards.

There are diverse schools of thought on how students should be measured or evaluated to show academic performance. According to Marlow (2003), teachers' written tests have been used for at least one hundred and fifty years to determine students' academic performance. The report of Coleman (1966) supports the view that non - school resources inputs such as students' family background factors contribute more to students' academic performance than the impact of school resources such as expenditure on teachers' salaries, laboratory facilities and equipment, books and quality of teachers. These variables according to Coleman (1966) have negligible effects on students' academic performance.

Any organisation that does not plan for its human resources will often find that it is meeting neither the personnel requirement nor its over-all goals effectively (Stoner, 1978). For example, a school may decide to introduce new subjects into its school curriculum, if the school does not make adequate arrangements for the teachers to handle these new subjects, the subjects will remain on the time table without being taught. To further buttress this point, when the federal government launched the 6:3:3:4 system of education, it spent huge financial resources on equipment for technical education. However, the human resources required to operate the equipment was not considered. Consequently, the equipment were left to rot in the rain and many of the equipment were eventually stolen by hoodlums.

With regards to the current educational policy, the supervision of instruction is the process of overseeing the work of teachers with the aim of assisting them to solve their instructional problems so that students can benefit maximally from classroom activities ( Igwe, 2005). This can be effected with the involvement of the principal or any other official appointed by interacting with teachers and students in the classroom regularly to monitor the teaching and learning process. According to Nwagwu (2004), the supervisor has the responsibility of monitoring and evaluating all staff activities and programmes of their organisation. The major reason for this is to ensure dutiful compliance of all staff with established laws and declared goals through quality assurance, maintenance of standards and quality control. This view is in line with the National Policy on Education (2004) which declared that supervision is a device for quality control. The goals of the school can be achieved through the continuous supervision of the teaching staff and the non- teaching staff.

The evaluation of staff is conducted as it determines their performance, in as much as it also determines the academic performance of students. In performance evaluation of staff, care should be exercised to ensure that it is the performance and not the personality of the employees that are evaluated (Okafor, 2006 ). In the study by Akposheri (1994), she found out that there was significant relationship between teachers who were highly rated during evaluation and the academic performance of students.

Another aspect of human resources management in the school is the workload of the staff. This is the amount of work assigned to a teaching position. Staff workload include teaching subjects, administrative duties, supervision of students and other activities. In the research findings on teachers' workload by Naylor and Malcomson (2001), teachers saw their workload increased because they spent fifty-three hours a week preparing their lesson notes for teaching and marking scripts. The teachers reported that they modified their teaching methods to enable them cope with the stress of the workload. When that happened, it was difficult for them to accomplish all their objectives because of the lack of time. Consequently, the performance of the teachers and the students was impaired.

Ikworayebe (2005) stated that in Edo State the allocation of teaching load to teachers is done through the number of periods of teaching. The maximum teaching workload per teacher is twenty-five periods while the minimum is eighteen per week. This policy is not strictly adhered to. Some teachers may be allocated less than the minimum teaching periods while others may have more than the maximum. This affects students' academic performance. In the junior secondary schools in the federal capital territory, Abuja, teachers' workload was one of the factors that inhibited students' performance ( Nwwikina and Nwanekezi (2010). They also stated that some teachers taught as much as thirty-five periods a week while others taught less than six periods. Such discrepancy indicated that the workload was not equitably distributed in the school. It would be preferable to have a uniform policy that will ensure an equitable distribution of teachers' workload that will enhance teaching and learning. The National Policy on Education (2004) stipulates a teacher student ratio of one to forty. However, a visit to some of the schools in Egor local government area revealed a clear departure from this policy. Teachers had classes with over a hundred students. This is due to the population explosion and the inability of the local government to employ more teachers. This situation has led to too much workload for the 
teachers. This certainly affects the academic performance of the students

\section{Purpose of Study}

The central research question that guided the study was, "What is the relationship between human resources variables and the academic performance of students in Egor local government area of Edo State, Nigeria"? The human resources variables employed for this study were: planning, staff supervision, staff evaluation and staff workload.

\section{Hypotheses}

1. There is no significant relationship between human resources planning and students' academic performance.

2. There is no significant relationship between staff supervision and students' academic performance.

3. There is no significant relationship between staff evaluation and students' academic performance.

4. There is no significant relationship between staff workload and students' academic performance.

\section{Methodologies}

The research is a relationship study with "ex -post facto" design. The design was found suitable as the interactions between the dependent and independent variables have occurred before this study. The population of this study consisted of public senior secondary school teachers and SS3 students in Egor local government area of Edo state in Nigeria. All the teachers and SS3 students in these schools constitute the target population for this study. The four hypotheses were tested using Pearson Product- moment correlation coefficient ( $r$ ) to determine the level of relationship between the variables and academic performance of the students.

\section{Results}

5.1 It was hypothesized that there is no significant relationship between human resources planning and students' academic performance.

Descriptive statistics

Human Resources Planning (HRP)

\begin{tabular}{|c|c|c|c|}
\hline & Mean & Std. Deviation & $\mathrm{N}$ \\
\hline HRP & 2.40 & .1218 & 11 \\
\hline \multicolumn{4}{|c|}{ Correlations Human Resources Planning (HRP) } \\
\hline & & Stud Perf & HRP \\
\hline \multirow{3}{*}{\multicolumn{2}{|c|}{$\begin{array}{l}\text { Stud Perf Pearson Correlation } \\
\text { Sig. (2tailed) } \\
\text { N }\end{array}$}} & 1.000 & .392 \\
\hline & & We & .233 \\
\hline & & 11 & 11 \\
\hline \multirow{3}{*}{\multicolumn{2}{|c|}{$\begin{array}{l}\text { HPR Pearson Correlation } \\
\text { Sig. (2-tailed) } \\
\text { N }\end{array}$}} & .392 & 1.000 \\
\hline & & .233 & - \\
\hline & & 11 & 11 \\
\hline
\end{tabular}

Note: Positively correlated but not significantly related

The hypothesis was accepted. The calculated correlation coefficient $r$ was 0.392 . Though it was not significant there was a positive relationship. Thus, the more there is human resources planning the better is the students' performance.

5.2 It was hypothesized that there is no significant relationship between staff supervision and students' academic performance.

Descriptive statistics

Staff Supervision (Staff Sup)

\begin{tabular}{|c|c|c|c|}
\hline & Mean & Std. Deviation & $\mathrm{N}$ \\
\hline Staff Sup & 2.80 & .1914 & 11 \\
\hline
\end{tabular}




\section{Correlations Staff Supervision (Staff Sup)}

\begin{tabular}{|l|c|c|}
\hline & Stud Perf & Staff Sup \\
\hline Stud Perf Pearson Correlation & 1.000 & .273 \\
Sig. (2tailed) & - & .417 \\
N & 11 & 11 \\
\hline Staff Sup Pearson Correlation & .273 & 1.000 \\
Sig. (2-tailed) & .417 & - \\
N & 11 & 11 \\
\hline
\end{tabular}

Note: Positively correlated but not significantly related

This hypothesis was accepted as the calculated correlation coefficient $r$ was 0.273 . Though it was not significant, staff supervision was positively related to students' academic performance. Thus, the more the staff are supervised the better is the students' performance.

5.3 It was hypothesized that there is no significant relationship between staff evaluation and students' academic performance.

Descriptive statistics Staff

Evaluation (Staff Eval)

\begin{tabular}{|c|c|c|c|}
\hline & mean & Std. Deviation & $\mathrm{N}$ \\
\hline Staff Eval & 2.49 & .1344 & 11 \\
\hline
\end{tabular}

\section{Correlations Staff Evaluation (Staff Eval)}

\begin{tabular}{|l|c|c|}
\hline & Stud Perf & Staff Eval \\
\hline Stud Perf Pearson Correlation & 1.000 & .400 \\
Sig. (2tailed) & - & .223 \\
N & 11 & 11 \\
\hline Staff Eval Pearson Correlation & .400 & 1.000 \\
Sig. (2-tailed) & .223 & - \\
N & 11 & 11 \\
\hline
\end{tabular}

Note: Positively correlated but not significantly related

The hypothesis was accepted as the calculated correlation coefficient $r$ was 0.400 . Though it was not significant, staff evaluation is positively related to students' academic performance. Hence the more the staff are evaluated the better is the students' performance.

5.4 It was hypothesized that there is no significant relationship between staff workload and students' academic performance.

Descriptive statistics

Staff workload (StaffWor)

\begin{tabular}{|c|c|c|c|}
\hline & mean & Std. Deviation & $\mathrm{N}$ \\
\hline Staff Wor & 1.79 & .2038 & 11 \\
\hline
\end{tabular}

Correlations Staff workload (StaffWor)

\begin{tabular}{|l|c|c|}
\hline & Stud Perf & Staff wor \\
\hline Stud Perf Pearson Correlation & 1.000 & -.106 \\
Sig. (2tailed) & - & .756 \\
N & 11 & 11 \\
\hline Staff wor Pearson Correlation & -.106 & 1.000 \\
Sig. (2-tailed) & .756 & - \\
N & 11 & 11 \\
\hline
\end{tabular}

Note: Negatively correlated and not significantly related 
The hypothesis was accepted as the calculated correlation coefficient $r$ was -0.106 . Staff workload has a negative relationship with students' performance. This implies that the lower the workload of staff, the better is the students' performance.

\section{Discussions of Results}

The positive relationship in human resources management planning is expected because planning is the bedrock of any organisation which intends to make an impact in society. The fact that there is no significant relationship indicates that much needs to be done in human resources planning sector in Egor local government area. The government should spend a considerable effort to recruit adequate staff in terms of quantity and quality and in particular to fill the areas of the most pressing needs. In-service training of staff should be a continual exercise, especially in their subject areas. Staff should be given the opportunity to attend seminars and workshops which would expose them to new methods of teaching and learning.

On staff supervision, the more the staff are supervised the better is the performance of the students. The insignificant relationship implies that supervision is not well conducted in senior secondary schools in Egor LGA. In a study of one thousand and eight primary and one hundred and five secondary schools in Edo State, only fifteen supervisors were in the inspectorate department of the Ministry of Education and only six of the supervisors had degrees in Educational Supervision (Ogunu, 2001). The present study has provided an insight into how supervision is carried out in secondary schools in Egor local government area. Since supervision is an important element in human resources management, it is therefore recommended that the inspectorate division of the Ministry of Education should be strengthened with more personnel to effectively carry out the function of staff supervision that will have a meaningful impact on students' performance.

Staff evaluation is also an important human resources management variable. The more the staff is evaluated the better is the students' performance. This result agrees with the views of Nwagwu (2004) that staff evaluation should be carried out to determine their performance because their performance also determines students' performance.

Staff workload has a negative relationship with students' academic performance. Hence the lower the workload of staff, the better is the students' performance. This finding agrees with those of Naylor and Malcolmson (2001) who reported that teachers had to adjust their teaching methods to enable them cope with the pressure of the workload. The finding from this study also agrees with the work of Nwikina and Nwanekezi (2010) who found out that in the federal capital territory (Abuja), teachers' high workload hindered students' academic performance but when their workload was reduced, students' performance improved.

\section{Conclusions}

There is no doubt that to achieve quality learning that will improve the academic performance of students, it is important that a system is put in place that will ensure that teachers, students and management are guided toward the desired goals and objectives of the school. This study explored such a system, that is, human resources management variables and how these variables influenced the academic performance of students. The study determined that staff workload had a negative correlation with students' performance while human resources planning, staff supervision and staff evaluation had a positive correlation to students' academic performance. However, they were all not significantly related to students' performance. The findings were consistent with those in the literature on school improvement.

\section{References}

Adeniyi, (2004). "Psychosocial Environment and Human Resource Management in Educational Institutions". Journal of Educational Management and Planning. Vol 1(1), pp. 141-152

Akposheri, R.O.(1994), The Relationship Between Students evaluation of Instruction and Students' Academic Performance. An Unpublished Masters Thesis. University of Benin, Benin City.

Coleman, J. (1966). Equality of Educational Opportunity", Washington D.C Department of Health Education and Welfare offices of Educations.

Igwe, S. O. (2005). Supervision, Evaluation and Quality Control in Education. In current Issues In Educational Management In Nigeria (Eds.) In N. A. Nwagwu., E. T.

Ehiametalor, M.A Ogunu, Mon Nwadiani (Eds). Current issues in Educational Management in Nigeria ( pp. 32-45). Association for 
Educational Administrator and Planning (NAEAP).

Ikworayegbe, M. G. (2005). The study Of Teachers Workload In Private and Public Secondary Schools in Edo North Senatorial District. Unpublished M.Ed Project, University of Benin, Benin City.

Marlow, E. (2003). Philosophy and Measurement of School Achievement. Journal of Instructional Psychology. http://www.findarticles. com

National Policy on Education (2004). Lagos: NERDC Printing press

Naylor, C. and Malcolmsom, J. D. (2001). A study of workload of English teachers in B.C.secondary grades. BCTR Research Report. RT01-0036 pp 16-17.

Nwagwu, N.A. (2004) Personnel Management. In N. A. Nwagwu., M. E. ljeoma., C. C.

Nwagwu (Eds). Organisation and Administration of Education.

Perspectives and Practices (pp 48 -55) Benin City. Festa Printing Press Ltd.

Nwikina, L. and Nwanekezi, A. (2010). Management of job-related teacher burnout in Nigerian schools. Academic Arena. 2(7).

Ogunu, M.A. (2001). Problems of School Inspection in Nigeria. In N.A Nwagwu, E.T

Ehiametalor. M. A. Ogunu and Mon Nwadiana (Eds). Current issues in Educational Management in Nigeria ( pp 60-65 ). Benin City. Association of Educational Administrator and Planning (NAEAP) .

Okafor, C. A. (2006). Organisational Characteristics, Practices, and Performance in Nigeria. A Ph.D Dissertation Submitted to School of Postgraduate studies, University of Benin, Benin City.

Peretomode, V. F. and Peretomode, O. (2005). Human Resources Management. Principles, Polices and practices. Lagos: Onosomegboho Ogbinaka Publishers Ltd.

Stoner, J. A. E. (1978). Management; New Jersey: Prentice Hall Inc. 